\section{Greenhouse dilemma}

SIR - Lave et al. ${ }^{1}$ contend that the global climate change research programmes in the United States and Europe "will do little to provide a solid scientific foundation for policy decisions in the next decade". The "management and focus" of these programmes, they argue, must be restructured and explicitly designed "to answer crucial policy questions" and "to produce answers when needed to policy makers". Their analysis is flawed as follows.

First, they call for a directed research programme in which tough administrators can discern which projects are "on target" and which are "wasteful". Implicit in this proposal is the assumption that we understand how the climate system works - that advances in fundamental knowledge (difficult to anticipate, much less produce on demand) are irrelevant. Yet within the past decade an 'ozone hole' has appeared over the springtime Antarctic $^{2}$, and anthropogenic aerosols ${ }^{3}$ and gases other than carbon dioxide ${ }^{4}$ have been recognized as having an effect on climate. These and many other 'discoveries' are highly relevant to policymaking and show, moreover, that the inadvertent global change experiment on which humanity has embarked remains largely uncharted territory.

Second, giving top priority to the needs of policy-makers assumes that policy-makers are in a dispassionate position to assess what information they require. The history of global change research, however, demonstrates that it will often produce information that governmental representatives find extremely inconvenient. We submit that the independence of scientific programmes from immediate policy concerns must be strengthened, not eliminated.

Third, it may be true that global change research will fail to provide clear policy guidance within the next decade, but blaming science for this failure and suggesting that tougher management could somehow force science to provide the policy-relevant answers displays a dangerously simplistic view of both the global climate and the way in which basic research influences public policy. It was free inquiry, not policy-orientated research, that uncovered the global warming problem in the first place (for example, refs 5 and 6 ) and that has led to every major advance in understanding since. These advances include the discovery of inherent complexities in the climate system (for example, feedbacks of unknown sign involving clouds, ocean currents and biota) - news that may be frustrating but is nevertheless important to policy-making.

Finally, Lave et al. assert that the agenda of research should not be "simply to advance knowledge" - a strange enough statement in a journal devoted to seeking scientific truth. Let's take note, however, that the pressing need to anticipate climate change is also an unprecedented opportunity to conduct Earth-systems research on the scale such research demands. Were this project to become a directed research effort, laid out in advance and held to a strict set of topics and timetables, the result would be certain disaster for basic science and a far greater likelihood of unexpected calamity for the Earth's inhabitants.

\section{T. L. Anderson}

\section{R. J. Charlson}

Department of Atmospheric Sciences,

University of Washington,

Seattle, Washington 98195, USA

J. A. Coakley

Department of Atmospheric

Sciences,

Oregon State University,

Corvallis, Oregon 97331 USA

1. Lave, L. B., Dowlatabadi, H., McRae, G. J. Morgan, M. G. \& Rubin, E. S. Nature 355, 197 (1992)

2. Farman, J. C., Gardiner, B. G. \& Shanklin, J. D. Nature 315, 207-210 (1985).

3. Charlson, R. J., Langner, J. \& Rodhe, H. Nature 348. 22 (1990).

4. Ramanathan, V., Cicerone, R.J., Singh, H. B. \& Kiehl, J. T. J. geophys. Res. 90, 5547-5566 (1985).

5. Manabe, S. \& Wetheraid, R. T. J. atmos. Sci. 24, 241 (1967).

6. Keeling, C. D. et al. Tellus 28, 538 (1976)

\section{Coelacanth tissue bank}

SIR - Coelacanths (Latimeria chalumnae) are accidental yet inevitable victims of the oilfish fishery on which depends the economy of the Islamic Republic of the Comores in the western Indian Ocean. Coelacanths die within a few hours of capture, and the impossibility of preventing coelacanth catches, as well as regulating trade in those that are caught, makes the long-term preservation of such material as is available imperative.

A feasible and effective way to do this would be a long-term programme of deep-freezing coelacanth material, so that it might be available for future generations of researchers to examine. To this end, the Max Planck Society has instituted just such a scheme.

In August 1991, a gravid female containing 26 late-term fetuses was caught off Mozambique - the only occasion, apart from the very first catch in 1938, on which any coelacanth has been caught outside the Comoro Islands. The specimen was given to Dr Cabral of the Maputo Natural History Museum in Mozambique, who donated frozen fetuses to the J. L. B. Smith Institute of Ichthyology in Grahamstown, South Africa, and the Max-Plank-Institut für Verhaltensphysiologie in Seewiesen, Germany. The Max-Planck specimens joined those of an adult and a sub-adult fish already deep frozen at $-80^{\circ} \mathrm{C}$. Tissue from this bank is available for scientific study on request, and interested researchers should address their enquiries to me.

\section{Hans Fricke}

Max-Planck-Institut

für Verhaltensphysiologie,

8130 Seewiesen (Post Starnberg),

Germany

(Fax: +498157 29209)

\section{National pride}

SIR - Your lamentation of crumbling empires and apprehension of emerging nation states (Nature 355, 659; 1992) is misplaced. That is the way of nature. The one overwhelming process that keeps life going is evolution, and you can't have evolution without competition. The more competitors, the better the chance of hitting the jackpot, so Mother Nature wants more diversity: more cultures, more languages, more nations.

Language differences among nations perform a very useful function as filters of information. By letting in desired information and excluding the rest, a nation can develop a very distinctive way of life, evolve in its own way. Thus, the more nations, the more ways of life, the better the chance that one of them will make an unprecedented leap of progress.

Perhaps the biblical fable of Babel has more truth in it than previously supposed, although in a perverse manner.

Andrejs Baidins

1104 Windon Drive,

Wilmington,

Delaware 19803, USA

\section{Rajiv Gandhi}

SIR - A recent News article (Nature 356, 185; 1992) about cooperation between Russia and India says that the former Indian leader, Rajiv Gandhi, was assassinated and thus removed from office. But in reality, he lost office when his Congress party was defeated in a general election. He had already been out of power for more than a year when he was assassinated.

N. P. Raju

c/o Prof. Dr. E, Gmellin,

Max-Planck-Institut

für Festkörperforschung,

Heisenbergstrasse 1 ,

7000 Stuttgart 80 ,

Germany 